\title{
Limiares entre ficção e história: elementos da personagem romanesca em Memórias de Branca Dias, de Miguel Real
}

\author{
Aldinida de Medeiros Sonza ${ }^{1}$ \\ Andréia Rafael de Araújo ${ }^{2}$
}

RESUMO: A metaficção historiográfica permite que a autoria dê asas aos mitos, elaborando personagens com maior ou menor reflexão crítica nas narrativas. O presente ensaio é um estudo que parte das relações entre Literatura e História no romance Memórias de Branca Dias (2009), de Miguel Real, publicado pela primeira vez em 2003, a fim de analisar a protagonista deste romance. A figura da Branca Dias real tornou-se um mito, lendas surgiram em torno deste nome; é uma personagem in presentia em algumas ficções, in absentia em outras. Buscamos identificar, com base n'A construção da Personagem Romanesca (2008), de Cristina Vieira, elementos que mostram um discurso crítico-reflexivo por parte da autoria de Miguel Real, o qual nos permite rememorar Branca Dias como uma mulher de luta, pois o romance, além de possibilitar que se retorne ao Brasil colonial, mostra a mão férrea da Igreja Católica no período da Inquisição, contra a qual Branca lutou a vida inteira.

PALAVRAS-CHAVE: História e literatura; Branca Dias; Metaficção historiográfica.

\section{Thresholds between ficction and history in Memórias of Branca Dias, of Miguel Real}

ABSTRACT: The historiographical metafiction allows authorship to give wings to the myths, elaborating characters with greater or less critical reflection in the narratives. The present essay is a study that starts from the relationship between Literature and History in the novel Memórias de Branca Dias (2009), by Miguel Real, in order to analyze the protagonist of this novel. The figure of real Branca Dias has become a myth, there are legends about this name; it is a character in presentia, in some fictions, in absentia in others. We seek to identify, based on $A$ construção da Personagem Romanesca (2008), by Cristina Vieira, elements that show a critical-reflexive discourse by the authorship of Miguel Real, which allows us to recall Branca Dias as a woman of struggle, because the novel, in addition to making it possible to return to colonial Brazil, shows the iron hand of the Catholic Church in the period of the Inquisition, against which Branca fought her entire life.

KEYWORDS: History and literature; Branca Dias; Historiographic metafiction.

[...] não podemos conhecer o passado, a não ser por meio de seus textos: seus documentos, suas evidências, até seus relatos de testemunhas oculares são textos. Até mesmo as situações do passado, suas estruturas e práticas sociais, podem ser consideradas, em certo sentido, como textos sociais (Linda Hutcheon, 1991, p. 34)

O romance histórico desde o modelo tradicional, no Romantismo, vem se modificando. Não é surpresa, pois, que a personagem na ficção histórica contemporânea tenha também se modificado. De salientar neste cenário de mudanças é a crescente representação feminina, seja

\footnotetext{
1 Professora colaboradora do Programa de Pós-Graduação em Literatura e Interculturalidade (PPGLI) da Universidade Estadual da Paraíba (UEPB). Coordenadora e líder do Grupo Interdisciplinar de Estudos Literários Lusófonos (GIELLus).

${ }^{2}$ Mestra em Letras pelo Programa de Pós-Graduação em Letras (PPGL) da Universidade Federal da Paraíba (UFPB). Integrante do Grupo Interdisciplinar de Estudos Literários Lusófonos (GIELLus).
} 
como protagonista ou personagem secundária, quer sob autoria feminina ou não.

O presente artigo traz uma leitura das especificidades da personagem protagonista do romance Memórias de Branca Dias, elucidando que a metaficção historiográfica possibilita as releituras críticas do passado, assentes na reflexividade. É esta construção de uma Branca Dias com elementos ideológicos próprios da escrita romanesca deste autor que estabelece os limiares entre a História e a Ficção. Para chegar a estes pormenores, empregamos os diversos elementos de construção da personagem romanesca, elencados e explicados por Cristina Vieira (2008) no ensaio A Construção da Personagem Romanesca: Processos Definidores.

A personagem é um importante elemento que caracteriza um romance. Sabemos que esta não é de uso exclusivo deste, faz-se presente em vários outros gêneros literários, todavia, é no romance que comporta a mais vasta carga de complexidade e destaque. É a partir dela que podemos entender o desencadeamento de um romance, pois, de acordo com Antonio Candido, "o enredo existe através das personagens; as personagens vivem no enredo" (1985, p. 53). Cientes disso, nada mais justo que reconhecer a vasta cadeia de significados e de processos que a constitui neste gênero.

Cristina Vieira (2008) levanta uma questão que certamente muitos de nós, hipoteticamente, nunca nos perguntamos: quantos de nós leitores não temos uma personagem que nos fascinou? Mas, será que já nos perguntamos quais estratégias levaram o autor a construí-la de maneira tão complexa?

O romancista é o responsável por essa demanda, dando sentido a esses seres fictícios. Mas é preciso atentar que "o significado das personagens não é, pois, dado simplesmente pelo autor, mas é construído pela tríade autor/ mensagem/ leitor” (VIEIRA, 2008, p. 34). A interpretação fica por conta do leitor, mas, é certo que toda uma compreensão apreendida desta, possivelmente tenha sido condicionada pelos recursos selecionados e utilizados pelo romancista e que consequentemente nos influenciaram para uma determinada visão.

É diante desta perspectiva que efetivamos a observação para mostrar quais os processos selecionados para a construção da protagonista do romance histórico de Miguel Real: Memórias de Branca Dias, que teve a primeira edição em 2003. Antes tendo consciência de que Branca Dias se encontra verdadeiramente na esfera histórica luso-brasileira. O enredo articula a vida de uma mulher vítima da estigmatização imposta nos séculos XVI-XVII por parte da Igreja Católica, face aos cristãos-novos. Branca Dias, descendente de judeus portugueses, enfrentou desde sua infância as perseguições por causa de sua origem religiosa. Visto pelo prisma histórico, o estabelecimento da Inquisição em 1536 em Portugal, que atingiu milhares de judeus, dentre eles toda a família de Branca, só veio a confirmar a verdadeira perseguição que os cristãos-novos 
enfrentariam. Esse é o contexto em que Miguel Real constrói a personagem Branca Dias no discurso ficcional.

De uma forma geral, Carlos Reis e Ana Cristina Lopes (2007) elucidam no Dicionário de Narratologia que a personagem dá vida, relevo e poder ao romance. Candido (1985) lembra que ela é fragmentária, isto quer dizer que nunca poderá alcançar a totalidade da representação do ser humano. O crítico ressalta também, em sua discussão, que na vida buscamos sempre entender as pessoas que são inerentemente misteriosas e propensas a mudanças, enquanto a entidade romanesca tem uma lógica própria: "No romance, o escritor estabelece algo mais coeso, menos variável" (CANDIDO, 1985, p. 58), ou seja, comparando a imensidão de personalidades das pessoas, o ser fictício tende a ser mais fixo. A complexidade e a tendência a ser profunda é o ponto comum entre personagem/pessoa, argumento apontado pelo crítico literário mencionado, ao falar da transição do romance do século XVIII que trouxe para o universo romanesco personagens mais complexas ancoradas em enredos simples.

Para além disso, não podemos esquecer de mencionar a importância do autor na elaboração do ser da ficção romanesca; ele utiliza várias estratégias para lhe dar vida, sendo assim, "a natureza da personagem depende em parte da concepção que preside o romance e das intenções do romancista" (CANDIDO, 1985, p. 74). O contexto e a vontade do escritor, dessa forma, moldam o indivíduo do romance. É a partir de toda essa sistemática de criação que o leitor pode julgar a desenvoltura desse ser inventado, postulando se retrata realmente a realidade ou se se sobrepõe às leis da verossimilhança. É por isso que o romancista se apoia em processos limitados para a edificação dessa categoria do romance.

\section{Processos de geração da personagem no romance}

A partir desse esboço, consideramos importante adentrar mais a fundo no estudo da personagem. Nessa perspectiva, o estudo de Cristina Vieira (2008) traz esse aprofundamento. Neste ensaio, a estudiosa sistematiza um imenso arcabouço teórico da personagem analisandoa através de macroprocessos, nos quais se desencadeiam processos, procedimentos e estratégias. Ela explica e exemplifica quase que minuciosamente dezenas deles, os quais foram organizados para discutir sob a perspectiva das seguintes áreas: linguística, retórica, narratologia, axiologia e semiologia-contextual.

Os primeiros, os processos linguísticos, são o suporte em que a personagem emerge. É a partir dessa base linguística que o leitor percebe os meios com que o autor arquitetou-a, ou seja, são "os primeiros processos construídos da personagem literária activados pelo autor e 
percepcionados pelo leitor" (VIEIRA, 2008, p. 40), esta, surgindo, majoritariamente, através do processo denominado de desembraiagem. Nesse processo, o romancista cria um "não eu", expulsando assim uma nova personagem de dentro de si para as entrelinhas romanescas, para o plano enunciativo. E para enunciá-la faz uso de outros processos acessórios desembraiadores, como: a cataforização que é a introdução desta pela primeira vez na narrativa; e a anaforização que se baseia em termos sintáticos subsequentes, que fazem o leitor ter um maior conhecimento do ser fictício, função esta dada aos designadores, outros procedimentos que ocorrem nesta vertente linguística. (VIEIRA, 2008).

Já os processos retóricos se configuram como elementos inevitáveis no processo da escrita de um romance, de tal modo que é a estratégia na qual a argumentação emerge (VIEIRA, 2008). O objetivo da retórica por vezes passa pela persuasão do leitor, vestígios da retórica antiga, contudo também tem fins de demostrar argumentos bem elaborados numa obra literária. Os principais processos aqui categorizados são os que fundam e transformam a entidade romanesca: os processos retórico-argumentativos, retórico-estilísticos e os retóricodispositivos. No processo retórico-argumentativo há a presença de conflitos e vontades, e a formação de identidades dos seres da ficção; no retórico-estilístico a linearidade do discurso é anulada, verdade/mentira não são contestados; destarte, o processo retórico-dispositivo consiste na articulação dos argumentos e das figuras dos outros processos (VIEIRA, 2008). É através dos raciocínios da retoricidade que se pode "assertar, negar, interrogar, provar, distinguir e assemelhar a personagem romanesca" (VIEIRA, 2008, p. 137) e não só isso, também na retórica estilística a sua identidade fica em jogo, podendo resultar ambiguidades e paradoxos.

Sobre os processos narratológicos encontrados na construção da personagem romanesca é necessário, primeiramente, considerar que a narração é característica inerente ao romance. Nela encontramos a personagem, que nesse estudo tomamos como cerne da narrativa e no tecido narrativo situa-se o plano do discurso e da história. Enquanto discurso, a narração remete ao ato de contar, ou seja, nas falas das personagens vê-se o desenrolar da trama. Já o plano da história designa os acontecimentos tecidos na narração correlacionados aos seres ficcionais. Por conseguinte, na história têm-se os elementos narrativos: ação, personagem, espaço, tempo e narrador. $\mathrm{Na}$ discursividade narrativa, esses elementos ganham mais corpo, pois "Se projetam as instâncias do narratário e do narrador, em cujo discurso e a partir do qual são geridos os discursos das personagens, as descrições, as manipulações temporais, a perspectiva narrativa e a focalização" (VIEIRA, 2008, p. 232).

Todos esses processos de alguma forma geram a personagem no romance: a ação, o 
tempo, o espaço, a cronotopização, a descrição, o narrador e a caracterização. Cada um tem sua parcela de contribuição na "arquitetura" do ser fictício. É propício mencionar que "não existe personagem fora da ação, nem existe ação independente do personagem" (TODOROV, 1979, apud VIEIRA, 2008, p. 235). É no plano discursivo que se constrói a ação e assim a personagem da narrativa romanesca ganha "maior autonomia face à ação" (VIEIRA, 2008, p. 236).

O tempo necessário a uma narração se divide em três estratégias, a primeira é a ancoragem temporal que é um procedimento desse processo; nela se sabe exatamente o tempo que a obra retrata. A segunda é a datação interpretativa, na qual o escritor usa o método de deixar implícito o tempo que a obra transcorre e, dessa forma, fica a ser captado pelo esforço do leitor. E a terceira é denominada de deixis temporal que só é percebida a partir da enunciação, termos como "hoje", "agora", "precisam o tempo diegético, mas não o determina no tempo cronológico" (VIEIRA, 2008, p. 260).

No tocante à espacialização, como o próprio nome já explicita, remete ao espaço narrado. Atribuído a esse processo temos os procedimentos da topicalização espacial que permite uma interpretação por parte do leitor para saber onde a personagem está; a programação espacial repercute no seu deslocamento, na multiplicação e/ou concentração dos espaços, nesse sentido, o espaço também enfatiza os objetos que compõem o espaço físico, social e psicológico. Outro processo narratológico, pouco conhecido, é a cronotopização que se configura na troca de papéis entre o tempo e o espaço. Por vezes "a espacialiazação ganha valor temporal e a temporalização ganha valor espacial” (VIEIRA, 2008, p. 296).

Já a narração como processo narratológico conduz esta edificação por meio do narrador e do narratário. Na narração autodiegética há uma síncrese, isto é, uma junção, entre o protagonista e o narrador. Enquanto a narração homodiegética "não só patenteia a oscilação entre os dois eus (eu-narrador e eu-narrado [...]), como também refere-se à distância mais ou menos cavada que eventualmente o separe do protagonista" (REIS; LOPES, 2007, p. 266; grifos dos autores). E na narração heterodiegética estabelece-se um afastamento em relação às personagens.

O quarto processo que a ensaísta nos traz é o da axiologização. O romance enquanto gênero crítico-reflexivo não foge à perspectiva ideológica. No discurso literário romanesco encontramos as mais variadas formas de expressão desses valores humanos. Neste sentido, é interessante observarmos como o ser fictício é moldado através desses processos axiológicos. Estes implicam os valores que o romancista o sujeita. Todavia, não depende apenas do escritor esta tarefa, pois os valores epocais exercem uma influência considerável na criação ideológica. 
Nisso, a axiologização desperta no leitor a competência do julgamento, mesmo que este julgamento possa ser condicionado pelo autor em passagens do texto.

Neste processo, os principais conceitos que serão abordados são: a norma, o valor, a axiologia e a ideologia - estes últimos vistos a partir de agora como sinônimos. O valor consiste em apresentar uma personagem como exemplo de valor social. A ideologia é a organização desses valores na sociedade. A norma estabelece que valor é certo e aceitável, podendo classificar também o contrário disso. Já a axiologização é todo esse sistema acertado nela, na personagem, e, uma vez construída axiologicamente, fica à mercê da crítica do leitor. Logo, o processo descrito ocorre a partir do juízo de valor do leitor em relação aos valores e atitudes contidos na obra face à personagem, ou seja, se lhe causar admiração ou repulsa, nessas ocasionais reações se concretiza o processo axiológico. E, para chegar a esse efeito axial se faz uso dos seguintes valores modais: "o da essência, o do saber, o do crer, o do fazer, o do poder, o do querer e o do dever" (VIEIRA, 2008, p. 360), ou seja, objetiva-se colocar em foco aquilo em que a personagem acredita e toma como verdade.

Por último, temos o uso de processos semiótico-contextuais que são os elementos intratextuais e extratextuais, dito de outra forma, são os elementos que remetem à obra literária propriamente dita, como um todo, e a textos exteriores à categoria narrativa. O contexto dá liberdade de ir-se além do texto escrito, ultrapassa o suporte onde é colocada e extrapola novos horizontes a partir dele. Pelas palavras de Vieira (2008), vemos que a construção do ser ficcional passa primeiramente pelo campo linguístico, mas é no âmbito extralinguístico que absorve uma ampla cadeia de significação oportunizada pelo escritor, visto que "a extensão das personagens romanescas pode limitar-se ao texto, mas não a sua intenção, aberta ao contexto.” (VIEIRA, 2008, p. 468).

Nesta retomada, ainda que resumida, constatamos que o processo de criação da personagem romanesca pode até não incluir, propositadamente, tantos e diversificados elementos. Mas pensamos que a Branca Dias de Miguel Real traz riqueza de detalhes e um discurso ideológico que merece ser esmiuçado.

\section{Branca Dias: elementos definidores de um discurso crítico e reflexivo}

Em Memórias de Branca Dias, a protagonista retorna ao passado e avalia suas vivências como judia refugiada. Branca Dias recorda toda sua trajetória desde Portugal até o Brasil, memórias de quem conseguiu escapar às garras da Inquisição. No enredo encontra-se o relato da sua vinda clandestina ao Mundo Novo, sua dificuldade de adaptação em Camaragibe, um 
dos primeiros engenhos de açúcar do Pernambuco, a ousadia de fazer sinagoga em plena vigilância inquisitorial, a convivência com os Tupinambás, seu relacionamento com o marido, Diogo Fernandes, e outros cristãos-novos, a criação de seus onze filhos nesta localidade e depois a residência em Olinda, onde funda uma escola para meninas. Branca Dias sempre conviveu com a mistura de culturas, a citar: a portuguesa, a brasílica, a dos negros africanos e a indígena, e, no sentido religioso, a dos cristãos e sua própria, a judaica.

Numa voz unívoca e continua, essa mulher emblemática na história luso-brasileira, a personagem centro-narrativa narra os fatos de sua vida e critica a Igreja Católica e o Tribunal Inquisitorial. A começar pelo prólogo, a oração à Adonai, nome judeu de Deus, percebeu-se que a obra trata também de questões religiosas. É como se, para contar suas memórias, Branca precisasse evocar a presença de seu Senhor, para direcionar sua fala, seus pensamentos, suas lutas, sua vida. Adonai é sua inspiração. Esse trecho revela a fidedigna judia que ela era:

Oh, quão grande é Adonai, louvado seja Ele em toda a sua grandeza. Não há palavras, gerações ou louvores que possam exprimir as suas obras, os seus benfeitos, a sua formosura, as suas maravilhas e grandezas; a sua honra e suas fortalezas. Recordem-se as suas lembranças, publicando sempre a sua justiça e o seu amor. (REAL, 2009, p. 19)

Por meio do discurso em primeira pessoa, autodiegético, apressado, próprio de quem conta a sua história rapidamente, querendo narrar tudo de modo a não esquecer nada, sem pausas, a narradora-personagem emerge uma voz contínua, que fragmenta a narrativa no tempo, pois enquanto relembra sua infância, num mesmo capítulo cita fatos de sua adolescência e fase adulta, e assim prossegue. Presente, passado e futuro estão constantemente interligados na narração de Branca Dias, visto que os fatos se correlacionam, isto é, quando se lê o texto pode-se constatar uma repetição de situações; são as lembranças que realmente significaram na vida da protagonista. Estas lembranças vão sendo repassadas ao narratário por meio de um discurso que aponta reflexões sobre a opressão religiosa.

No tecido do romance passamos a conhecer a história. A protagonista reconstruiu sua trajetória em Portugal e no Brasil. Denunciada pela mãe e pela irmã ao Tribunal Inquisitorial, foi presa nos Estaus com os sete filhos que já possuía e desprovida da presença do marido, que já havia fugido para o Brasil, foi presa e sentenciada a dois anos de prisão. Fugiu num navio negreiro, para uma terra desconhecida, o Brasil-colônia, o Mundo Novo, mas nem neste lugar, onde a Inquisição não havia chegado, pode professar sua fé livremente. Em contrapartida, Branca Dias resistiu a seu modo, pois ela, seu marido e outros cristãos-novos fizeram esnoga (sinagoga) em Camaragibe, localidade onde o governador Duarte Coelho confiou que 
administrassem um engenho. Aquela que na historiografia luso-brasileira iria ser conhecida como uma das primeiras senhoras de engenho, mestra laica de meninas e a primeira cristã-nova a fazer sinagoga no Brasil colonial açucareiro, fez realmente celebrações, conforme a Tradição Mosaica:

Quando vim para Camaragibe disse logo ao Diogo, temos de fazer esnoga, eu disse, estamos livres, disse eu, não há Santo Ofício no Brasil, disse eu, mal sabia que havia de chegar, já está na Bahia, daqui a uns três anos chega a Olinda, ai as minhas filhinhas; o Diogo respondeu, não sei, disse ele, temos que fazer esnoga, disse eu, e ele viu pelo meu dizer que tínhamos mesmo de fazer esnoga, e fizemos, o Diogo no princípio sempre contrariado, não sei, dizia ele, eu sei, dizia eu, e fizemos. (REAL, 2009, p. 120)

Dez anos depois da morte do marido, Branca faz residência em Olinda, e mesmo lá, uma cidade mais perto do poder central da Capitania, uma cidade com mais Igrejas e Mosteiros, sendo mais perigosa uma demonstração pública, continuava a "judaizar". Vale lembrar que o medo que circundava Branca Dias era a chegada do Visitador da Inquisição, Heitor Furtado de Mendonça, em Olinda, pois mesmo depois de morta, poderia ser delatada, e as principais vítimas a serem perseguidas seriam suas filhas, como a própria prevê:

Tenho medo de que as minhas filhas ainda venham a pagar rijamente por isso, elas que, coitadas, não percebiam nada do que se passava, vai ser difícil ocultar ao Visitador que durante anos e anos se fez esnoga em Camaragibe, [...] os cães vão saltar para cima das minhas filhas, eu já lhes conheço as manhas [...]. (REAL, 2009, p. 121)

Com a visita do representante Heitor Furtado de Mendonça, no século XVI, que permaneceu no Brasil nos anos de 1591 a 1595, filhos e netos da matriarca foram presos, enviados para Lisboa, e julgados. A genealogia apresentada no quarto capítulo do livro realça essa afirmação histórica, e esses dados no corpo da diegese enfatizam a ligação com a História (Cf. REAL, 2009, p. 34-35).

Contextualizado o enredo da obra, prossigamos para a análise da construção da protagonista em questão. Decerto, para a elaboração de uma entidade ficcional, o romancista precisa fazer uso de certos mecanismos a fim de construí-la de forma íntegra, consoante ao fato de não serem "formas vazias ou 'puros operadores" (AGUIAR E SILVA, 2009, p. 694).

Nos processos linguísticos, os primeiros citados por Cristina Vieira (2008), configuramse os planos que a personagem emerge narrativamente, "na medida em que ela foi tecida de palavras pelo autor e é nesse mesmo suporte que ela é apresentada ao leitor" (VIEIRA, 2008, p. 39). A protagonista do nosso corpus de pesquisa, Memórias de Branca Dias (2009), como todo e 
qualquer ser inventado do romance, surge através de um processo primordial da desembraiagem: o indicador da personagem no plano enunciativo da narrativa.

No caso da narrativa sobre Branca Dias, temos uma síncrese da protagonista e da narradora, autodiegética, que são as mesmas. A Branca Dias idosa e vivida traz as reminiscências da sua vida quando criança, adolescente e adulta, tendo um relevo consubstancial na narrativa inteira. Portanto, a própria se apresenta no romance; vejamos o respectivo fragmento: “apresentou-me ao Governador Coelho, era Vossa Mercê para aqui, Vossa Fidalguia para acolá, esta é a minha senhora, Branca Dias a seu dispor, disse eu, aflita a compor os cabelos, a ajeitar o vestido" (REAL, 2009, p. 27). Esta conversação se baseia na chegada da matriarca ao porto de Olinda, quando seu marido, à sua espera, apresenta-a ao donatário da província de Pernambuco.

Assim, a designação da protagonista é feita de maneira motivada; acreditamos que Miguel Real não escolheu aleatoriamente esta personagem, dado que a motivação "pode ter raízes extra-textuais (sic), ligadas ao contexto pessoal e histórico-cultural do autor" (VIEIRA, 2008, p. 111). Outra designação que compete ao romancista é a titulação do livro e, neste caso, temos o próprio nome da protagonista no título que ainda alude à temática de memórias.

Respectivamente, os processos retóricos também se auxiliam do plano linguístico para exercer função na constituição da personagem romanesca. Toda a vasta cadeia de argumentação de um romance assenta na retoricidade. Nesta protagonista ressaltamos como ativos os argumentos baseados na estrutura do real, com a argumentação à base da aplicação de regras de justiça e a argumentação pela reciprocidade. Estes tipos de argumentações são comuns em romances com forte carga ideológica, pois podem conter ironicamente a ridicularização de alguma regra, no caso desse livro, regras impostas pela Igreja Católica:

\footnotetext{
Chamavam-nos cristãs-novas, obrigavam-nos a ir à missa ao domingo, vigiavam a nossa casa ao sábado e tínhamos de nos confessar e comungar três vezes por ano, uma no Natal, outra na Páscoa e outra já não me lembro quando. (REAL, 2009, p. 69).
}

Devido às regras implantadas pelo Catolicismo, era apropriado nos séculos XVI-XVII, todos os portugueses terem uma vida religiosa ativa, porém nem todos eram cristãos fidedignos, principalmente os cristãos-novos que nem tiveram tempo de assimilar a nova religião de tão repentina que foi a conversão forçada. Apesar de estar situada no período do Humanismo/Classicismo, a história de vida de Branca Dias parece situada nos calabouços da Idade Média: 
Ainda a título de contextualização, não podemos falar em Idade Média sem mencionar o poder temporal e espiritual da Igreja Católica, que a tudo encobriu por um breu de proibições, dogmas e tabus, a fim de que o controle social fosse cada vez mais exercido pela religião. (MEDEIROS, 2019, p. 65).

Voltando à personagem, nos argumentos fundacionais da estrutura do real percebemos o processo argumentativo da ilustração, que dá um relevo maior à protagonista, dando ênfase ao movimento e à sua atuação no enredo. Também a ilustração pode se servir da ironia, no sentido "subjacente serve ora à ridicularização, ora à recriminação axiológica da personagem que desmente na acção ou nas palavras a ilustração feita a seu propósito" (VIEIRA, 2008, p. 178). Para exemplificar, vejamos a rememoração da protagonista:

confirmei a denúncia de minha mãe e de minha irmã, que sim, que ao sábado metia camisa e beatilha lavadas e punha matulas novas nas candeias à sextafeira, deixando esta acesa toda a noite, e acrescentei que jejuava em todos os dias prescritos pela Lei Velha, engolia logo a hóstia mal o padre ma servia, só não a trincava porque os outros percebiam, se não era logo uma trincadela, que só burros é que podem acreditar que o Messias está ali em corpo, ajoelhava-me em frente do Crucificado imaginando que era Adonai que estava presente, e não rezava o pai-nosso e a avé-maria, que os sabia, eu sabia, disse eu a Martim Afonso, mas em silêncio rezava a Adonai antigas preces que minha avó ensinara. (REAL, 2009, p. 41)

Ao assumir que não acredita no Deus católico e enfatizar sua continuação nos costumes da Lei Velha, a dos judeus, vê-se que ela não se converteu verdadeiramente à fé cristã, por outro lado, a narradora ridiculariza-a quando diz "que só burros é que podem acreditar que o Messias está ali em corpo" (REAL, 2009, p. 41). Ressaltamos que esta passagem também dialoga com a argumentação pelo antimodelo, pois nestas palavras revela-se uma mulher que não segue o padrão modelar esperado pela sociedade arraigada por ideologias religiosas.

Nos processos narratológicos, simultaneamente, o ato de contar faz a gênese da personagem no romance. Por ter caráter tipologicamente narrativo, esse gênero, permite o advento do ser fictício, pois, sem ele, o texto literário perderia sua essência, se tornaria inviável. Afirma a ensaísta que a personagem é o "epicentro dos fenômenos narratológicos" (2008, p. 227). Consideramos que o tempo da obra aqui analisada se baseia na estratégia da datação interpretativa, termo criado por Vieira (2008). Neste tipo de tempo, o romancista dá indícios da época, inferindo no romance, fatos históricos ocorridos no ocasional período. No fragmento abaixo, em nenhum momento Real especifica datas:

Entre o baptismo em pé no Rossio de Lisboa e a chegada da Inquisição a Portugal, ainda que tivesse ouvido falar de matanças na judiaria de Lisboa, 


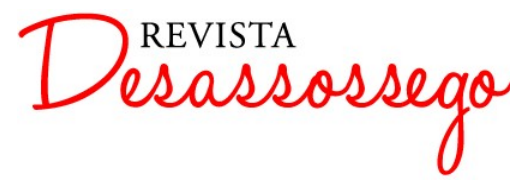

DESASSOSSEGO 20 - parte 2 | JUN/2019 | ISSN 2175-3180

DOI: http://dx.doi.org/10.11606/issn.2175-3180.v11i20p286-300

em Viana nenhum judeu foi perseguido, já nos tinham feito cristãos-novos, estavam sossegados, os nazarenos; sentiam-se bem, deixavam-nos em paz, durante uns anitos, até começarem a berrar que éramos marranos, judaizávamos. (REAL, 2009, p. 97)

A citação, que não contêm menção de anos, aborda o fato histórico do batismo forçado em 1497, promulgado pelo rei D. Manuel, e a instauração da Inquisição, em 1536, por isso fica por responsabilidade do leitor interpretar quando sucedeu tal fato. Branca Dias viveu em dois espaços, neste romance, em Viana (Portugal) e em Pernambuco (Brasil), estes espaços, com efeito, influenciaram o andamento da sua vida. Sobre sua construção no âmbito da espacialização, o romance nos direciona à motivação espacial, que afeta "o determinismo do meio, ao determinar-lhe ficcionalmente a vida e o caráter" (VIEIRA, 2008, p. 294).

Em relação à focalização, podemos dizer que o escritor faz uso da focalização heterodoxa, que "permite que personagens individuais ou coletivas habitualmente marginalizadas ganhem estatuto diferencial" (VIEIRA, 2008, p. 305). Sobre o tipo de narrador presente nesse texto, consideramos ser autodiegético, pois verdadeiramente há uma síncrese entre a protagonista e a narradora.

Por conseguinte, a ideia de que existe uma carga ideológica expressiva no romance é o que fundamenta nosso olhar para as representações femininas. Não há como um gênero como o romance, tão próximo das questões humanas, se desviar de tal característica. Sobretudo por acreditarmos que a área dos Estudos de Gênero, advinda dos Estudos Culturais, além de ter empreendido o resgate da autoria feminina, possibilitou a desconstrução dos estereótipos atribuídos à mulher, representados nas obras literárias. Logo, “[...] implica dizer que para os estudos de gênero e para a literatura que busca resgatar o lugar do feminino na História, o romance histórico tem uma importância estético-temática considerável” (MEDEIROS, 2019, p. 103).

A personagem, na sua vez, é o espelho resultante desses processos. Ao buscarmos compreender os processos axiológicos, encontramos a carga ideológica que o romance oferece, uma vez que traz essa característica de sugerir ao leitor, pelo menos em nossa percepção, um pouco da sua realidade, de seus valores humanos e julgamentos sociais. Com base no aporte teórico aponta-se que “a axiologização suscita juízos de valor sobre a personagem que, podendo não estar manifestos na tessitura textual, são estimulados junto do leitor, ou seja, a axiologização contribui para a caracterização indirecta da personagem” (VIEIRA, 2008, p. 350).

É pelo viés deste processo que o Memórias de Branca Dias se inscreve como um romance de fatores ideológicos bem definidos. Os valores exigidos pela Igreja Católica se configuram estáticos de uma dada sociedade e período histórico. Em termos axiológicos, Branca Dias por 
ser judia, ou melhor, uma cristã-nova que judaizava em sigilo, tinha atitudes e valores ideológicos que causavam repulsa à sociedade da época:

[...] nós tentamos disfarçar, tudo era feito em segredo e em silêncio, mas os nazarenos bem percebiam, principalmente na Lua Nova de Agosto, nas festas de Kipur e Sacot, a festa das cabanas; as carroças saíam de Olinda ornamentadas de ramos e espadanas os arcos das mulas todos floridos, as famílias todas empoleiradas abrindo a picada para Camaragibe, era impossível não dar nas vistas, iam-se ao campo comer, mas eram só cristãos-novos que iam, eles bem percebiam, lá vão eles judaizar, diziam eles, vão para Camaragibe judaizar, diziam eles. (REAL, 2009, p. 120-121)

Chama-se modalização o processo que o autor emprega um valor modal à personagem romanesca. A que ocorre acima, no texto literário, é a modalização veridictória, que tem relação com o verbo "ser", um predicado de estado, que "origina quatro modalidades que lexicalizam quatro tipos de relações ser/parecer: a verdade, a mentira, a falsidade e o segredo" (VIEIRA, 2008, p. 361). No entanto, analisando a protagonista, não encontramos a incidência de personalidade falsa. Branca Dias viveu em uma sociedade onde ser judeu era ser inferior religiosamente, por isso para escapar aos olhos vigilantes do Santo Ofício, não mostrava verdadeiramente sua essência, praticava sua fé em sigilo, e mentia para a sociedade cristã. Todavia, a mentira nem sempre é associada à falsidade.

Outro valor modal que associamos a essa judia é a modalização epistémico-emocional, em que opera o verbo "crer", originando personagens confiantes na sua crença. No prólogo da narrativa há uma intensa oração ao Deus dos judeus, Adonai. A judia enfatiza ser a Lei Judaica a única que Deus quis, o povo judeu foi escolhido, ou seja, excluía as outras possibilidades de fé religiosa:

Adonai, meu Deus e Deus de meus pais, permiti, Senhor, livrar-me hoje e em todo o dia do malfeitor e da má obra, [...] Adonai, Senhor saboreia nossos rogos, imprimindo nas nossas bocas e nas bocas de nossos filhos e na dos filhos dos nossos filhos palavras Vossas, fazendo que verdadeiramente todos conheçam o seu Santo Nome e a sua Santa Lei. Bendito, Adonai nosso Rei e Rei de todo mundo, que escolheu em nós mais que em todos [...]. (REAL, 2009, p. 19)

A modalização factiva é outra observada na protagonista. A situação que comprovamos ser relacionada com este valor modal é quando a protagonista é presa junto com seus filhos e, para não ser torturada, confessa suas culpas ao inquisidor. Esta modalização "indica que a intervenção da personagem $\mathrm{X}$ sobre a personagem $\mathrm{Y}$, ao coincidir com a rejeição da personagem Y, consubstancia as modalidades de [...] intimidação, depreciadas se gerarem 


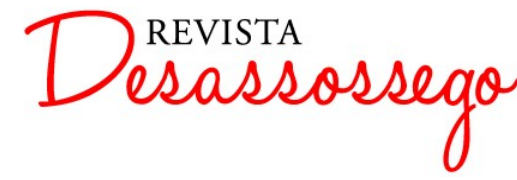

DESASSOSSEGO 20 - parte 2 |JUN/2019 | ISSN 2175-3180

DOI: http://dx.doi.org/10.11606/issn.2175-3180.v11i20p286-300

injustiça" (VIEIRA, 2008, p. 368). Autos-de-fé, torturas, são exemplos desse processo. Se

Branca não falasse conforme o interrogador queria ouvir, ela seria torturada:

Sofri duas admoestações do cabrão do Martim Afonso, e eu sabia que à terceira ia para os calabouços da tortura, eu ouvia-os durante o dia, aos torturados na polé, gemidos, de frémitos, pareciam balidos, depois de novo berros, brados, pareciam ganidos; eu não conseguia suportar aquilo e acabei por confessar tudo. (REAL, 2009, p. 41)

Para concluir nossa análise, conforme a sequência do ensaio, em seguida temos os processos semiótico-contextuais; neles observamos a importância do contexto na elaboração da protagonista aqui analisada. O contexto condiciona sua desenvoltura. Os elementos intratextuais e extratextuais dão significado ao contexto da obra, seja pela ação, tempo ou espaço ou pela intertextualidade (VIEIRA, 2008).

A intencionalidade do autor, no ato de construção do romance, interfere na criação das personagens. Nesta perspectiva, a protagonista passa pelo processo chamado pesquisa documental, no qual o autor estuda fontes pertinentes para sua construção. Miguel Real, certamente fez uso desse esquema, buscando na historiografia a Branca Dias que a posteriori desenharia na ficção, porque "acontecimentos históricos marcantes, leituras feitas e exploração de arquétipos" (VIEIRA, 2008, p. 479) são alternativas que o romancista tem para compor sua obra literária. De acordo com o processo mencionado, abaixo vemos um fragmento que traz figuras e situações colhidas, certamente, nos registros históricos. Aqui se vê a desconfiança das meninas da escola de Branca Dias, que, posteriormente, fizeram denúncias:

E vai ser difícil que estas meninas, que agora já são senhoras, não delatem o que viveram na minha escola ao Heitor Furtado da Fonseca, ninguém no Pernambuco está a salvo da Inquisição e a melhor maneira de nos desembaraçarmos das suspeitas é lançarmos as suspeitas para cima dos outros, vai ser um regabofe de acusações contra Branca Dias e as suas filhas. (REAL, 2009, p. 136-137)

A referencialização é outro processo semiótico-contextual que ocorre no romance estudado e na personagem que o protagoniza, sabendo que "a conformidade às referências históricas é uma exigência de figurativização referencializante, ao contrário do que sucede na construção de personagens que pretendem ser meramente verossímeis" (VIEIRA, 2008, p. 525). Para tanto, o romancista pode fazer uso, como já foi mencionado, da pesquisa prévia documental e da posterior figurativização realista, termos retirados do ensaio em questão. Nesta fala de Branca, há referência a uma das situações históricas em que ficou conhecida, que foi ter 
administrado um engenho em pleno Seiscentos: "O Diogo morreu e não fui para Olinda, fiquei a tratar do engenho, devo ter sido a primeira mulher do Brasil a ser senhora de engenho" (REAL, 2009, p. 48). Para o autor mencionar isso, este deve ter encontrado indícios concretos de que Branca Dias foi realmente o que narra ter sido.

Em suma, os processos semiótico-contextuais falam da possibilidade do autor pensar no que vai projetar em seu romance, em especial na personagem romanesca. É o antecedente ao ato de escrever a obra, as motivações ou intenções que levam o autor a escrever determinado tipo de ser narrativo inventado. Assim, é certo que as ideias do contexto da obra influem na escolha do romancista, na recepção do leitor e na enunciação do ser fictício.

\section{Considerações Finais}

Por meio da construção da protagonista Branca Dias, de Miguel Real, passamos a conhecer a história dessa judia perseguida pelo Santo Ofício, personagem que singulariza a luta da nação judaica no Brasil, que sofreu com a desenfreada caça inquisitorial em meados de Seiscentos/Setecentos, começada em Portugal.

Outrossim, esta sua representação romanesca não a torna uma mulher com aspecto de vítima; pelo contrário, constatamos esta judia como uma mulher que não baixou a cabeça para uma instituição tão poderosa, como era a Igreja Católica no dado período. É, segundo a "tinta" de Miguel Real, uma mentalidade à frente das mulheres de sua época, sem traços de submissão. Medeiros (2015) afirma: "Isto nos leva a ressaltar os traços psicológicos desta protagonista: altiva, prudente, perspicaz, paciente, porém não conformada [...]” (p. 21). E, de figura histórica duplamente marginalizada e perseguida, ressurge nesta metaficção historiográfica com merecida grandeza, na condição de uma personagem complexa.

A partir dos elementos definidores prescritos por Vieira (2008), que encontramos na narrativa de Miguel Real, vimos que a personagem Branca Dias foi constituída, ao longo da narrativa, como uma mulher forte na sua crença, determinada e que a partir de sua história verídica e marcante, não caiu no esquecimento, e foi reproduzida na Literatura de modo a problematizar os valores do indivíduo na relação com uma época. Com efeito, a protagonista foi elaborada de maneira complexa e consistente, com uma carga ideológica bastante ampla, argumentos bem fundamentados, valores e contexto questionados, todos interligados a uma cadeia de narração, na qual o tempo, o espaço, a focalização, a narradora e o título, entre outros, foram elaborados com fortes recursos axiológicos. 


\section{1 esassos sego}

Referências:
DESASSOSSEGO 20 - parte 2 |JUN/2019 | ISSN 2175-3180

DOI: http://dx.doi.org/10.11606/issn.2175-3180.v11i20p286-300

AGUIAR E SILVA, Vítor Manuel de. O romance: história e sistema de um gênero literário. In: Teoria da Literatura. 8. ed., Coimbra: Almedina, 2009.

CANDIDO, Antonio. A personagem do romance. In: A personagem de fiç̧ão. São Paulo: Perspectiva, 1985.

HUTCHEON, Linda. Poética do Pós-Modernismo: história, teoria e ficção, Rio de Janeiro, Imago, 1991.

MEDEIROS, Aldinida. Mulheres no romance histórico contemporâneo português. Curitiba: Appris Editora, 2019.

MEDEIROS, Aldinida. Memórias de Branca Dias: um discurso necessário à memória dos judeus perseguidos. Revista Historia, 6 (1), P. 9 - 27. Recuperado de Disponível em: https://periodicos.furg.br/hist/article/view/5139 Acesso em: 10/01/2020

REAL, Miguel. Memórias de Branca Dias. 3. ed. Lisboa: Quidinovi, 2009.

REIS, Carlos; LOPES, Ana Cristina M. Dicionário de Narratologia. 7. ed., Coimbra: Almedina, 2007.

VIEIRA, Cristina Maria da Costa. A Construção da Personagem Romanesca: Processos Definidores. Lisboa: Colibri, 2008. 